\title{
Pembuatan Alat Pintar Pengusir Burung Di Sawah Dengan Sumber Energi Mandiri
}

\author{
${ }^{1)}$ E. Nurcahyo, ${ }^{2}$ M. A. Hamid,${ }^{3}$ N. P. Agustini, ${ }^{4)}$ A. F. Rachmatilah, N. R. Yusuf, Y. S. Dzuha, Rhesal, Reza. \\ ${ }^{1), 2), 3)}$ Dosen Teknik Listrik DIII, Institut Teknologi Nasional Malang \\ ${ }^{4)}$ Mahasiswa Teknik Listrik D.III, Institut Teknologi Nasional Malang \\ Email: ekonur@lecturer.itn.ac.id
}

\begin{abstract}
Dalam pembuatan alat ini peneliti bertujuan untuk membantu para petani yang memiliki sawah agar dapat lebih mudah dalam cara mengusir hama burung yang dapat menyebabkan gagal panen pada sawah petani. Dalam perancangan alat ini dilakukan analisa lapangan yang ada pada sawah petani dan analisa bahan material yang akan dipasang pada alat Pengusir Hama Burung). Dalam pengoperasiannya, mekanisme alat ini mudah digunakan karena dioperasikanya dengan motor DC sebagai penggeraknya, sedangkan untuk kelistrikannya menggunakan kendali Arduino Uno yang berasal dari Accumulator $12 \mathrm{~V}$ dengan sumber energinya berasal dari Cell Surya yang disalurkan ke accumulator untuk menyimpan energi sinar matahari dan menyalurkannya ke Arduino Uno sebagai kendali dan ke motor DC sebagai pengerak untuk menghasilkan gerakan untuk membuat burung pipit tidak memakan padi yang ada di sawah petani. Adapun pergerakan dikendalikan dengan Handphone menggunakan Bluetooth. Jarak pengendalian ini hingga mencapai 40 meter dari peralatan.
\end{abstract}

Keywords : Hama burung, Arduino Uno, Cell Surya, Bluetooth

\section{Pendahuluan}

Hama adalah organisme yang dianggap merugikan dan tidak diinginkan dalam kegiatan sehari-hari manusia. Suatu hewan dapat dikatakan hama jika menyebabkan kerusakan pada ekosistem alami atau menjadi agen penyebaran penyakit dalam habitat manusia. Dalam pertanian, hama adalah organisme pengganggu tanaman yang menimbulkan kerusakan secara fisik, dan menyebabkan kerugian dalam pertanian.

Burung adalah salah satu hama bagi petani. Kerusakan paling parah akibat hama burung yaitu gagal panen. Burung biasa menyerang tanaman padi secara koloni atau berkelompok. Burung dapat menimbulkan kerusakan pada padi yang menjelang panen. Serangan burung hama padi mengakibatkan banyak biji yang hilang sehingga padi tidak ada bijinya. Tingkat kerusakan akibat serangan hama burung sangat fatal bagi petani, yaitu gagal panen dan kerugian ekonomi lain yaitu meningkatnya biaya produksi karena adanya penambahan tenaga kerja untuk mengusir burung yang menyerang tanaman padi,karena hama burung terhadap tanaman padi kini hanya dilakukan dengan cara tradisional.

Suara-suara bising dapat membuat hama burung panik dan menjauh dari pusat bunyi tersebut. Selain suara-suara yang bising, hama burung juga takut dengan gerakan yang tiba-tiba.

Sehingga dibuatkan suatu alat untuk mengusir hama burung dengan alat pengusir burung berbasis wireless kontrol menggunakan bluetooth

\section{METODE KEGIATAN PENGABDIAN KEPADA MASYARAKAT.}

a) Tahap Pengumpulan fakta dan informasi

Kegiatan ini dimulai dari melakukan survey pada para petani padi. Padi yang menjelang masa panen adalah makanan yang di sukai hama burung pipit yang ada di sekitaran sawah, hal ini membuat hasil panen para petani menurun karena di serbu ratusan burung pipit.

b) Tahap Indentifikasi dan perumusan masalah

Dalam hasil survey didapatkan bahwa terjadi permasalahan pada saat para petani mengusir hama burung pipit. Para petani tidak punya cukup waktu luang hanya untuk menunggu padinya selama seharian karena takut akan di serang hama burung pipit.

c) Tahap Studi Literatur

Untuk memperkuat ide dilakukan studi literature melalui internet dan buku buku referensi

d) Tahap perencanaan

Menyusun rencana pelaksanaan dan pembuatan alat Pengusir Hama Burung Pipit Via Wireless

e) Pembuatan alat 
Dalam pembuatan alat ini menggunakan arduino uno untuk menangkap signal SMS yang akan menggerakkan motor DC dan akan menghasilkan gerakan yg akan mengusir burung pipit. Alat ini menggunakan sumber listrik dari cell suryadan untuk penyimpanan energi listriknya menggunakan accumulator.

f) Uji coba

Uji coba alat dilakukan setelah alat selesai dibuat. Pengujian alat dilakukan di sawah dekat kampus 2 ITN MALANG.

g) Evaluasi progam

Melaksanakan review dan evaluasi terhadap setiap kondisi dari alat yang telah diuji coba dan diimplementasikan. Jika terjadi kesalahan pada alat,maka akan langsung dilakukan perbaikan. Evaluasi juga digunakan untuk pengembangan alat kedepannya.

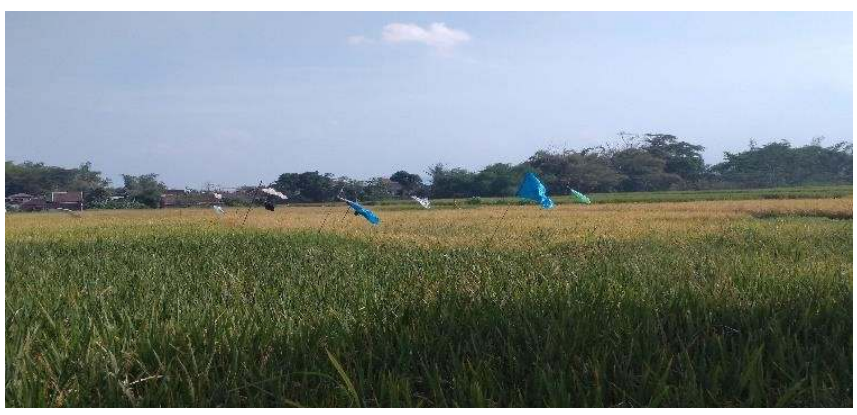

Fig. 1. Survey ke Lokasi Sawah di Kmps2 ITN Malang

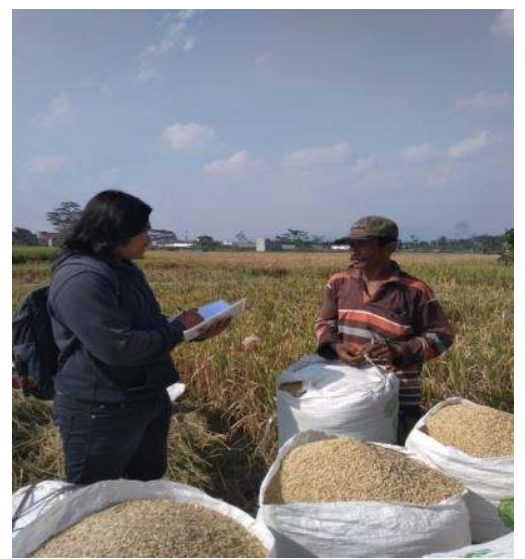

Fig. 2. Survey ke Petani

\section{LANDASAN TEORI}

\section{Pengertian Motor Listrik}

Motor listrik merupakan sebuah perangkat elektromagnetis yang mengubah energi listrik menjadi energi mekanik. Energi mekanik ini digunakan untuk, misalnya, memutarimpeller pompa, fan atau blower, menggerakan kompresor, mengangkat bahan, dan lain sebagainya. Motor listrik digunakan juga di rumah (mixer, bor listrik, fan atau kipas angin) dan di industri. Motor listrik dalam dunia industri seringkali disebut dengan istilah "kuda kerja" nya industri sebab diperkirakan bahwa motor-motor menggunakan sekitar $70 \%$ beban listrik total di industri. ${ }^{[2]}$

Prinsip kerja motor listrik pada dasarnya semua jenis motor secara umum adalah :

- Arus listrik dalam medan magnet akan memberikan gaya

- Jika kawat yang membawa arus dibengkokkan menjadi sebuah lingkaran/loop, maka kedua sisi loop, yaitu pada sudut kanan medan magnet,akan mendapatkan gaya pada arah yang berlawanan.

- Pasangan gaya menghasilkan tenaga putar/ torque untuk memutar kumparan.

- Motor-motor memiliki beberapa loop pada dinamonya untuk memberikan tenaga putaran yang lebih seragam dan medan magnetnya dihasilkan oleh susunan elektromagnetik yang disebut kumparan medan.

- Dalam memahami sebuah motor, penting untuk mengerti apa yang dimaksud dengan beban motor listrik. Beban mengacu kepada keluaran tenaga putar/ torque sesuai dengan kecepatan yang diperlukan. Beban umumnya dapat dikategorikan kedalam tiga kelompok ${ }^{[3]}$ : 
- Beban torque konstan adalah beban dimana permintaan keluaran energinya bervariasi dengan kecepatan operasinya namun torque nya tidak bervariasi. Contoh beban dengan torque konstan adalah conveyors, rotary kilns, dan pompa displacement konstan.

- Beban dengan variabel torque adalah beban dengan torque yang bervariasi dengan kecepatan operasi. Contoh beban dengan variabel torque adalah pompa sentrifugal dan fan (torque bervariasi sebagai kwadrat kecepatan).

- Beban dengan energi konstan adalah beban dengan permintaan torque yang berubah dan berbanding terbalik dengan kecepatan. Contoh untuk beban dengan daya konstan adalah peralatan-peralatan mesin.

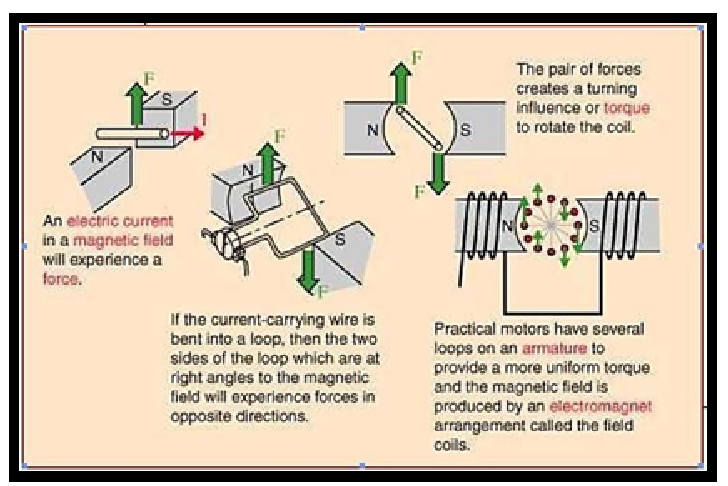

Fig. 3. Prinsip Dasar kerja motor listrik ${ }^{[3]}$

\section{Arduino Uno ${ }^{\{6\}}$}

Kata " Uno " berasal dari bahasa Italia yang berarti "satu", dan dipilih untuk menandai peluncuran Software Arduino (IDE) versi 1.0. Arduino. Sejak awal peluncuran hingga sekarang, Uno telah berkembang menjadi versi Revisi 3 atau biasa ditulis REV 3 atau R3. Software Arduino IDE, yang bisa diinstall di Windows maupun Mac dan Linux, berfungsi sebagai software yang membantu anda memasukkan (upload) program ke chip ATMega328 dengan mudah.

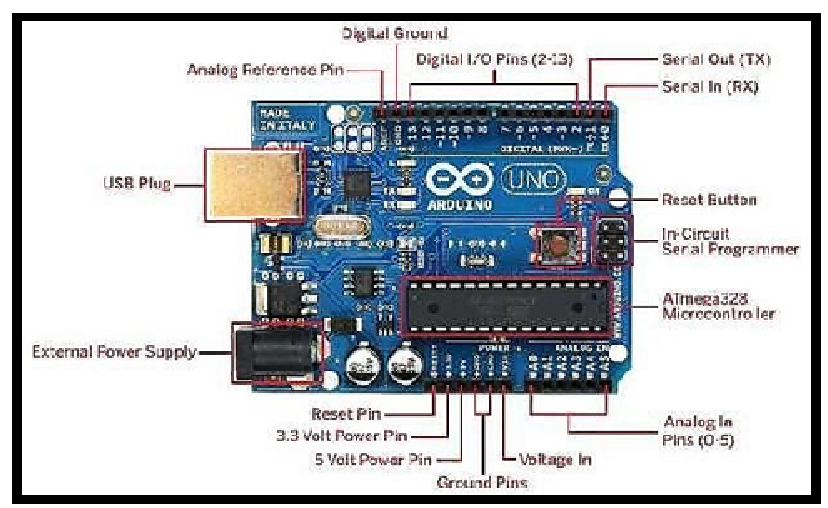

Fig. 4. Arduino Uno

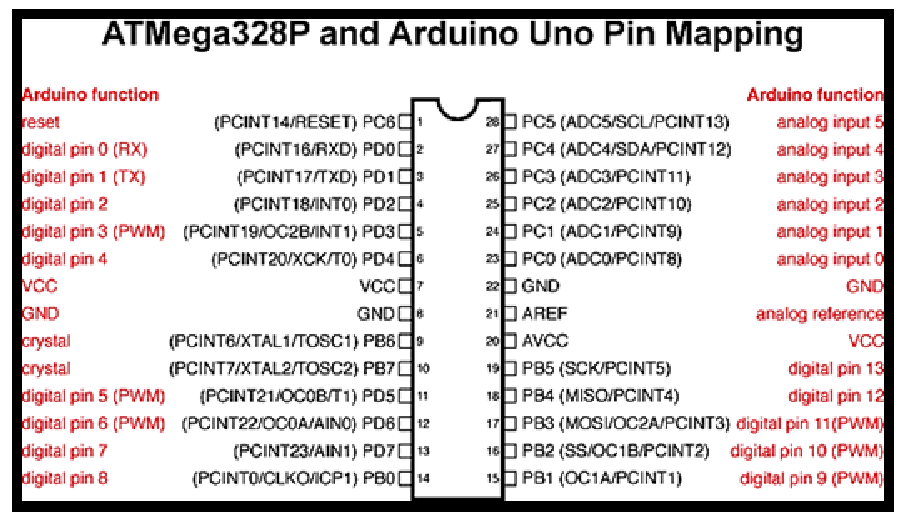

Fig. 5. Pin Chip Atmega328P 


\section{SEL SURYA}

Sel surya atau juga sering disebut fotovoltaik adalah divais yang mampu mengkonversi langsung cahaya matahari menjadi listrik. Sel surya bisa disebut sebagai pemeran utama untuk memaksimalkan potensi sangat besar energi cahaya matahari yang sampai kebumi, walaupun selain dipergunakan untuk menghasilkan listrik, energi dari matahari juga bisa dimaksimalkan energi panasnya melalui sistem solar thermal.

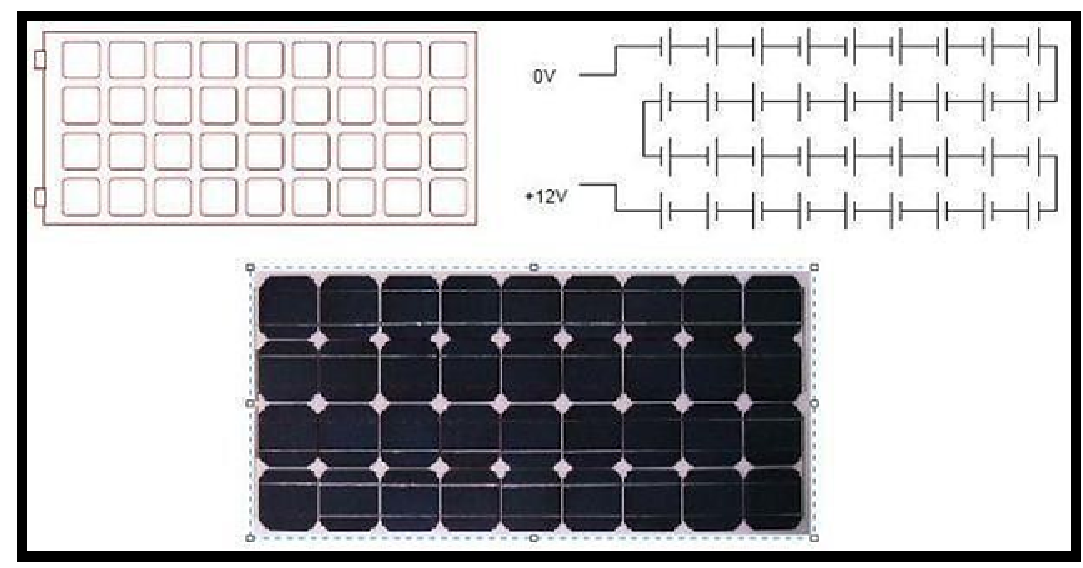

Fig. 6. Bentuk Fisik Sel Surya ${ }^{[10]}$

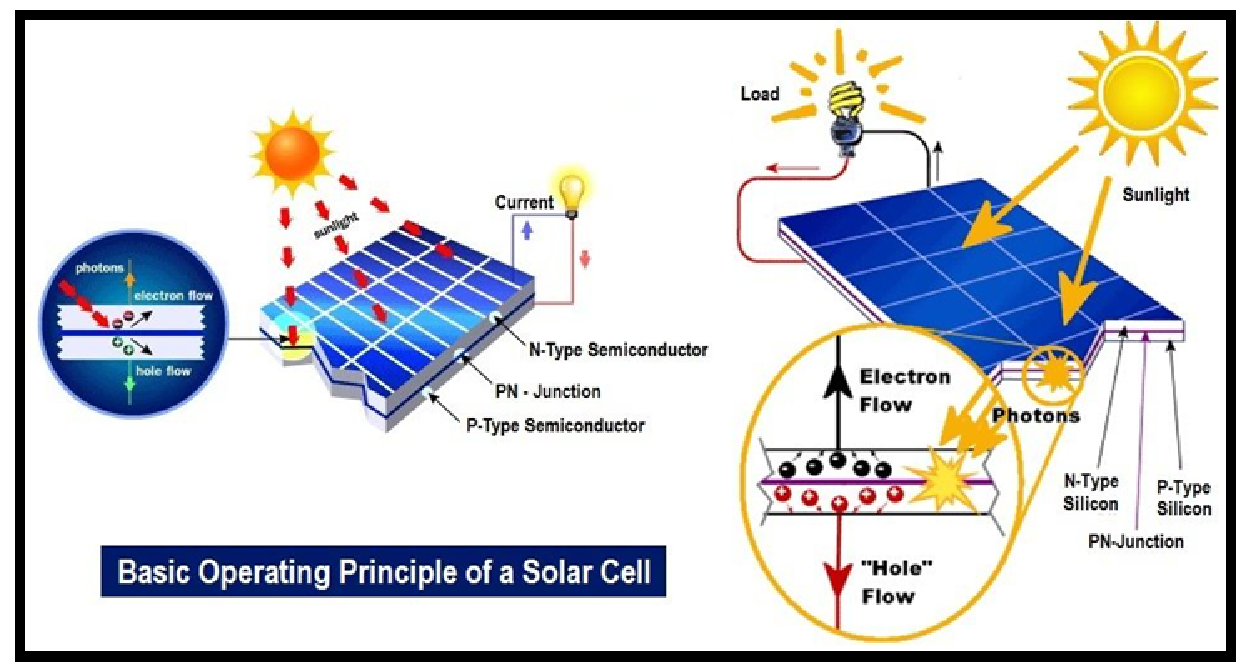

Fig. 7. Ilustrasi Cara Kerja Sel Surya Dengan Prinsip P-N Junction ${ }^{[1]}$

\section{MOTOR DRIVE IC L293D}

IC L293D adalah IC yang didesain khusus sebagai driver motor DC dan dapat dikendalikan dengan rangkaian TTL maupun mikrokontroller. Motor DC yang dikontrol dengan driver IC L293D dapat dihubungkan ke ground maupun ke sumber tegangan positif karena di dalam driver L293D sistem driver yang digunakan adalah totem pool. Dalam 1 unit chip IC L293D terdiri dari 4 buah driver motor DC yang berdiri sendiri - sendiri dengan kemampuan mengalirkan arus 1 Ampere tiapdriver. Sehingga dapat digunakan untuk membuat driver Hbridge untuk 2 buah motor DC. 


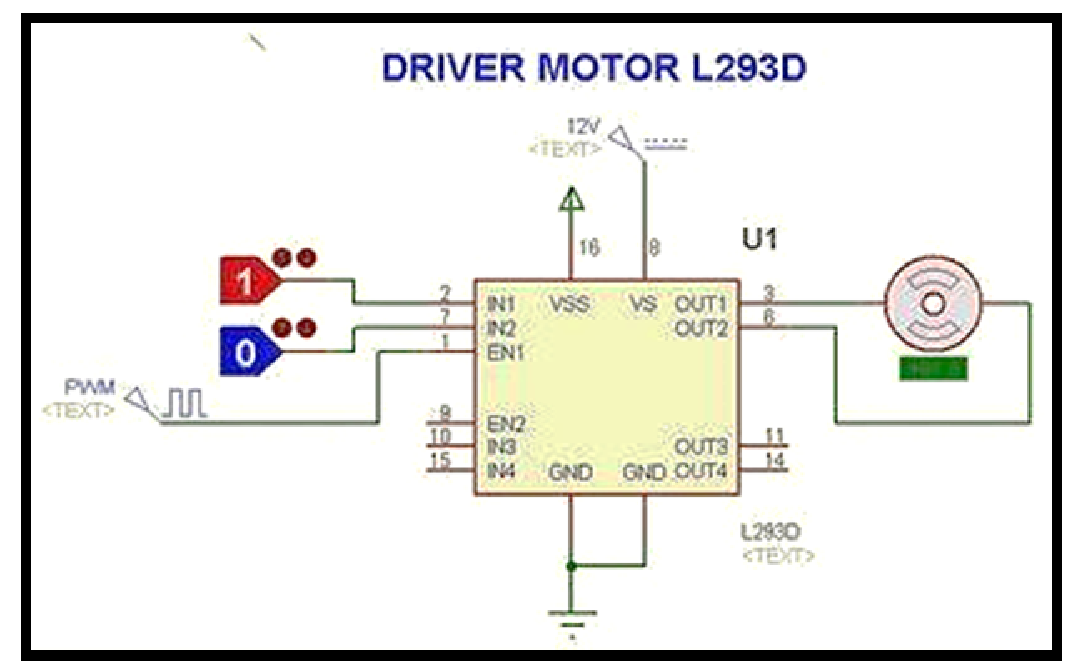

Fig. 8. IC Driver Motor Tipe L293D ${ }^{[12]}$

Proses Perancangan Dan Pembuatan Bagian Mekanis, Elektris, Pemrograman Serta Perakitan
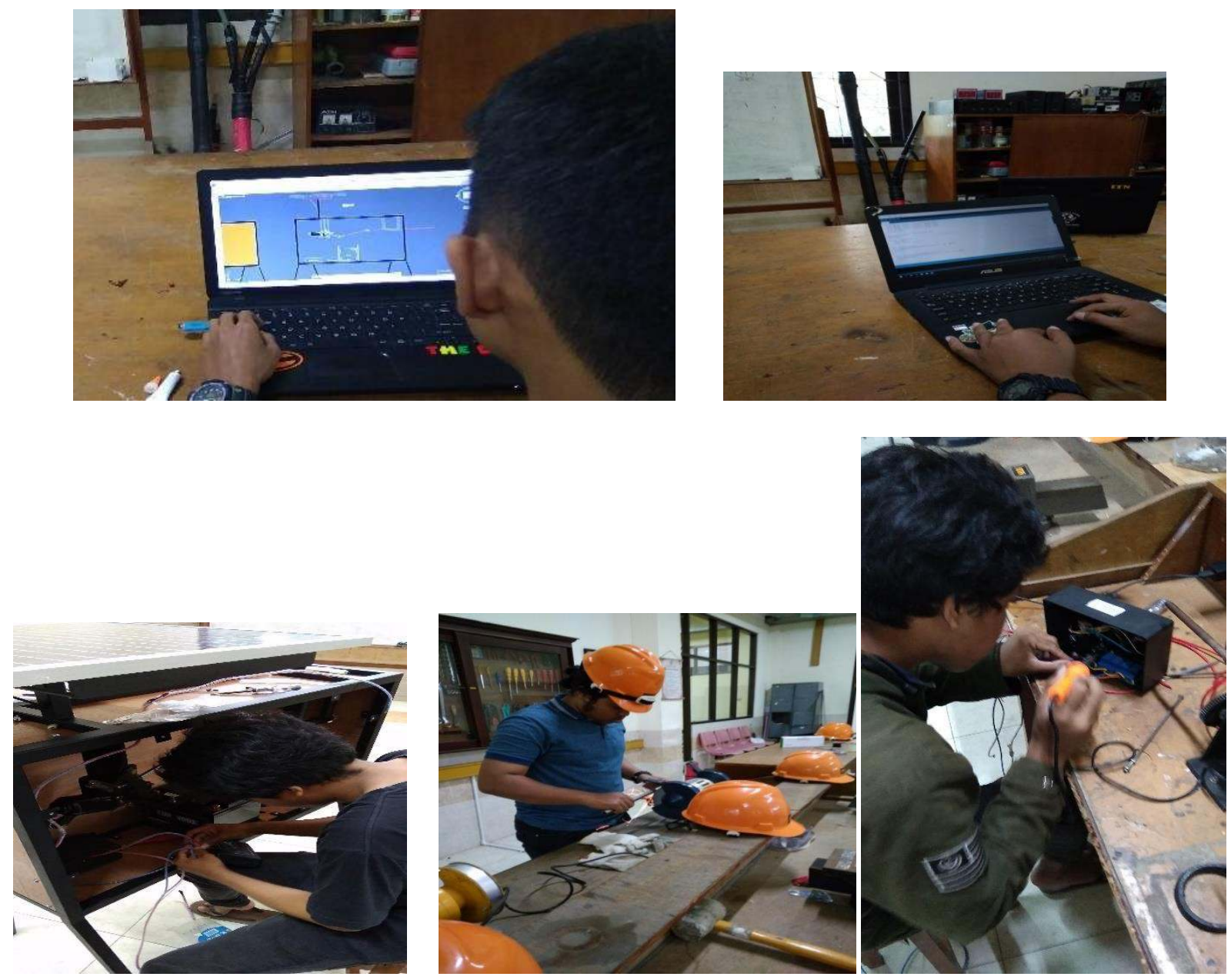

Fig. 9. Proses Pembuatan Alat 


\section{Mengaktifkan bluetooth}

Bluetooth akan bekerja bila bluetooth ditekan dan terdapat list bluetooth yang tersedia, selanjutnya pilih bluetooth yang akan dihubungkan dan selanjutnya sistem akan menghubungkannya, berikut 2 kondisi sebelum dan sesudah tombol ditekan :

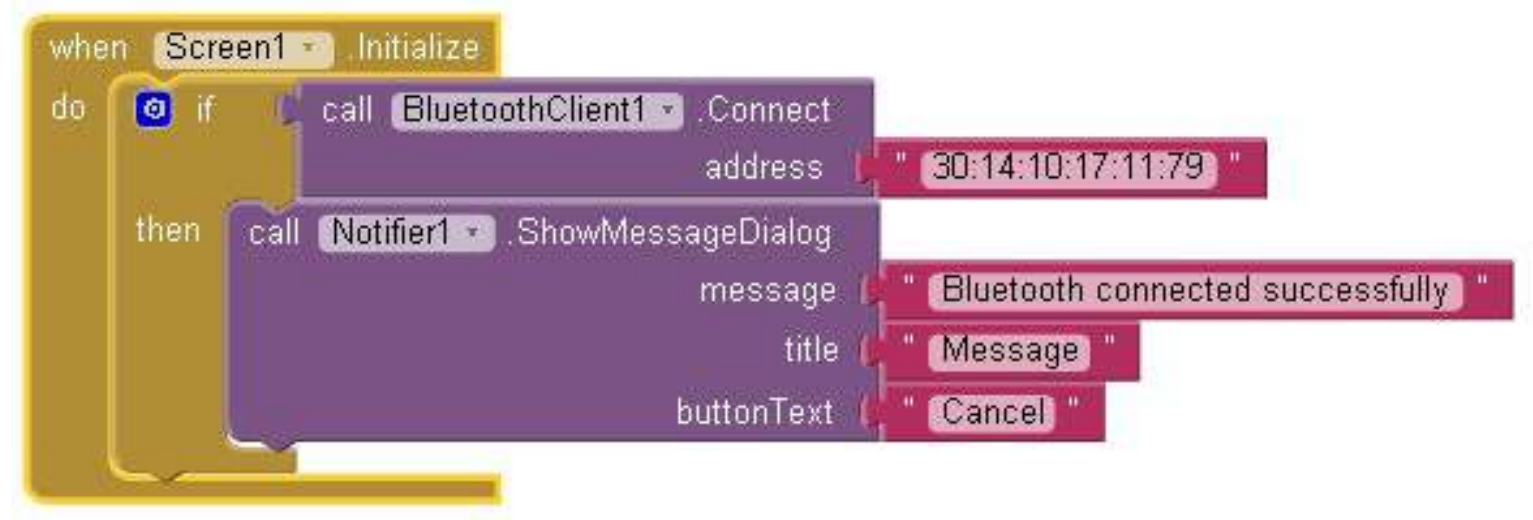

Fig. 10. Mengaktifkan bluetooth

\section{Fungsi Clock}

Clock berfungsi untuk menunggu renspon bluetooth dimana bluetooth terhubung setelah beberapa saat atau tidak terhubung, clock ini juga dapat ditambahkan set lainnya seperti menuliskan terhubung atau tidak pada label yang sudah ditentukan, berikut block untuk settingclock :

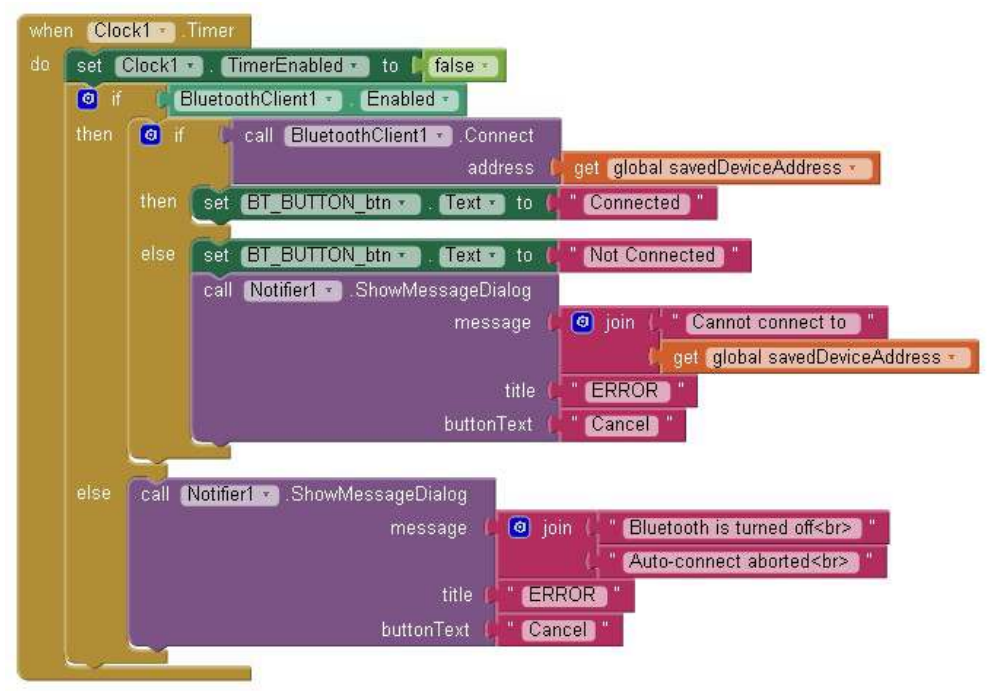

Fig. 11. Fungsi Clock

\section{DATA DAN PENGUKURAN}

Alat dan Bahan yang dibutuhkan selama pengukuran adalah sebagai berikut :

- Modul/Prototipe Pengatur Kecepatan Motor DC

- Handphone berbasiskan Android (complete aplikasi control)

- Volt Meter Digital (APPA 100 Series)

- Tachometer

- Solar Cell

- Driver Motor DC IC L293D

- Akumulator (Accu) NS40ZLS, 12 Volt, $40 \mathrm{AH}$ 


\section{Pengukuran Rangkaian Pengendali Kecepatan Motor DC}

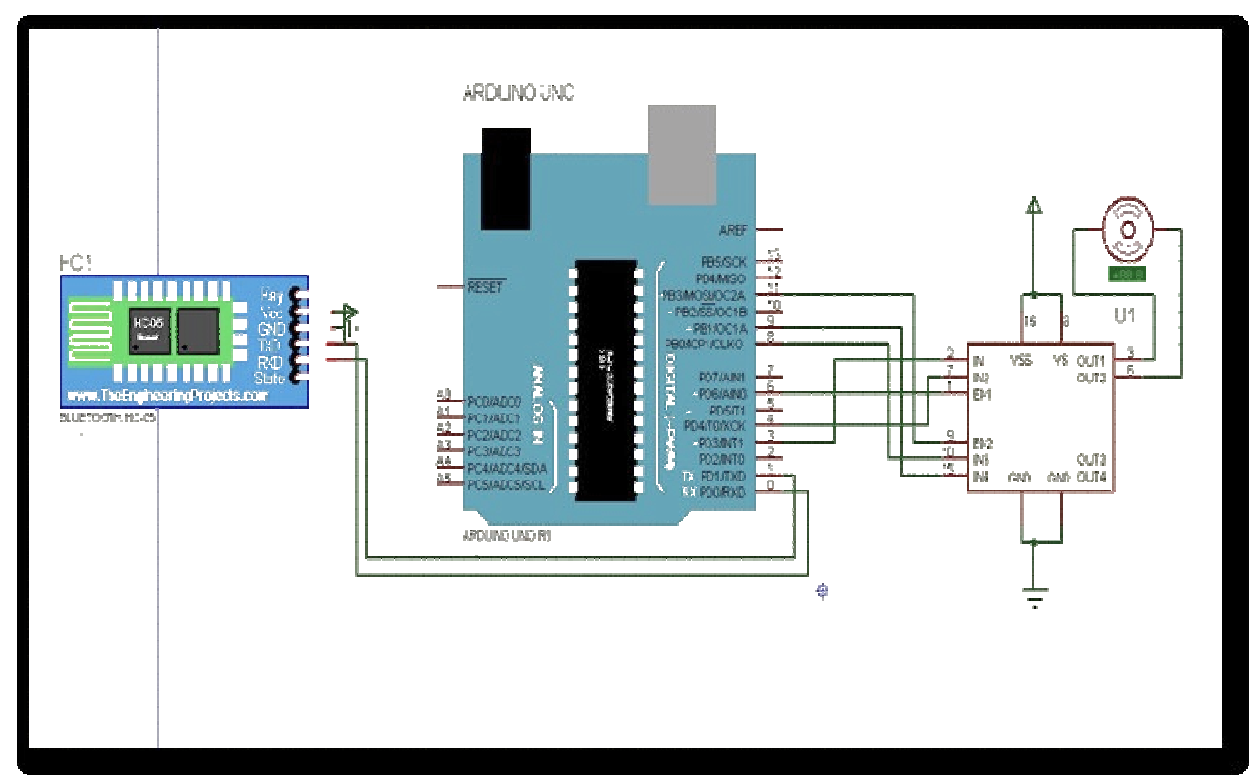

Fig. 12. Simulasi Rangkaian Pengendali Kecepatan Motor DC

Data primer diperoleh dari hasil pengukuran langsung terhadap prototipe yang dibuat.

\begin{tabular}{llll} 
TABLE I. & PENGUKURAN ARUS PADA SAAT MOTOR TERPASANG ATAU BERBEBAN \\
\hline Kecepatan & $\begin{array}{l}\text { Imax Arduino } \\
\text { (Amp) }\end{array}$ & $\begin{array}{l}\text { Arus Motor } \\
\text { (Amp) }\end{array}$ & $\begin{array}{l}\text { Tegangan Motor } \\
\text { (Volt) }\end{array}$ \\
\hline $100 \%$ & 0,04700 & 0,2137 & 12 \\
$75 \%$ & 0,04700 & 0,2089 & 12 \\
$50 \%$ & 0,04700 & 0,1879 & 12 \\
$25 \%$ & 0,04700 & 0,1729 & 12 \\
$0 \%$ & 0,0000 & 0,0000 & 0,0000 \\
$-25 \%$ & 0,04700 & 0,1599 & 12 \\
$-50 \%$ & 0,04700 & 0,1897 & 12 \\
$-75 \%$ & 0,04700 & 0,2099 & 12 \\
$-100 \%$ & 0,04700 & 0,2137 & 12 \\
\hline
\end{tabular}

Rata-rata arus pada motor $=0,194575$, sedangkan rata-rata tegangan 12 Volt, maka daya rata-rata yang dibutuhkan motor untuk bekerja adalah :

$$
\begin{aligned}
\mathrm{P} & =\mathrm{V} \times \mathrm{I} \\
& =12 \times 0,194575 \\
& =2,3349 \text { Watt. }
\end{aligned}
$$

Dari hasil pengukuran diperoleh data kecepatan Motor DC dalam satuan RPM, berikut perbandingan kecepatan per menit menjadi ke detik : 
E. Nurcahyo, M. A. Hamid, N. P. Agustini,A. F. Rachmatilah, N. R. Yusuf, Y. S. Dzuha, Rhesal, Reza.

TABLE II. PENGUKURAN KECEPATAN MOTOR DC

\begin{tabular}{lll}
\hline Kecepatan & $\begin{array}{l}\text { Motor } \\
(\text { Rpm })\end{array}$ & $\begin{array}{l}\text { Motor } \\
(\text { Detik })\end{array}$ \\
\hline $100 \%$ & 3421 & 56 \\
$75 \%$ & 1699 & 27 \\
$50 \%$ & 1055 & 15 \\
$25 \%$ & 81 & 1 \\
$0 \%$ & 0 & 0 \\
$-25 \%$ & 90 & 3 \\
$-50 \%$ & 1067 & 21 \\
$-75 \%$ & 1844 & 32 \\
$-100 \%$ & 3161 & 53 \\
\hline
\end{tabular}

TABLE III. Pengukuran Jarak Kontrol atau Bluetooth

\begin{tabular}{llll}
\hline No & Jarak (meter) & Terhubung / Tidak & Keterangan \\
1 & 0 & Terhubung & Motor bergerak \\
2 & 5 & Terhubung & Motor bergerak \\
3 & 10 & Terhubung & Motor bergerak \\
4 & 15 & Terhubung & Motor bergerak \\
5 & 20 & Terhubung & Motor bergerak \\
6 & 25 & Terhubung & Motor bergerak \\
7 & 30 & Terhubung & Motor bergerak \\
8 & 35 & Terhubung & Motor bergerak \\
9 & 40 & Terhubung & Motor bergerak \\
10 & 45 & Terhubung & Motor bergerak \\
11 & 50 & Terhubung & Motor bergerak, tersendat-sendat \\
12 & 55 & Terhubung & Motor kadang bergerak, kadang tidak \\
13 & 60 & Tidak Terhubung & Motor tidak bergerak \\
14 & 65 & Tidak Terhubung & Motor tidak bergerak
\end{tabular}

\section{Pengukuran Pada Solar Cell}

Pengujian ini bertujuan untuk mengetahui kondisi solarcell saat terkena sinar matahari, untuk mengetahui karakteristik tegangan solarcell terhadap waktu, dan juga untuk mengetahui tegangan puncak pada solarcel

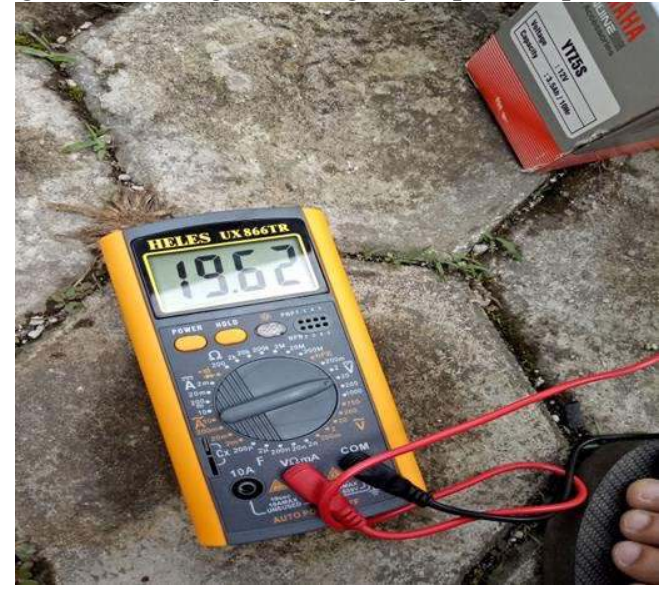

Fig. 13. Hasil Pengukuran Solar Cell 
TABle IV. Hasil Pengujian Keluaran Arus dan Tegangan Pada Solar Cell

\begin{tabular}{lllll}
\hline No & Cuaca & Waktu & $\begin{array}{l}\text { Tegangan } \\
\text { Solarcell }(\text { Volt })\end{array}$ & $\begin{array}{l}\text { Arus } \\
\text { Solarcell }(\mathrm{A})\end{array}$ \\
\hline 1 & Terang & 8.00 & 18,10 & 0,27 \\
2 & Terang & 9.00 & 18,53 & 0,32 \\
3 & Terang & 10.00 & 19,24 & 0,40 \\
4 & Terang & 11.00 & 19,24 & 0,45 \\
5 & Terang & 12.00 & 19,51 & 0,59 \\
6 & Terang & 13.00 & 19,62 & 0,65 \\
7 & Terang & 14.00 & 19,56 & 0,53 \\
8 & Terang & 15.00 & 19,24 & 0,45 \\
9 & Terang & 16.00 & 18,54 & 0,26 \\
\hline
\end{tabular}

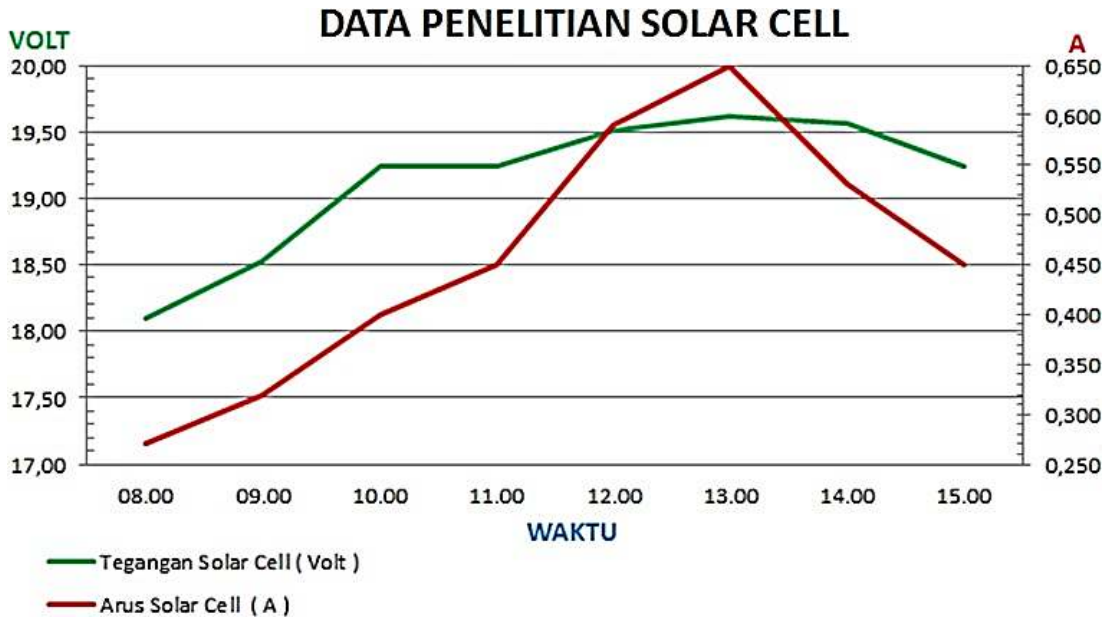

Fig. 14. Grafik Data Penelitian Solarcell

Dari hasil penelitian di atas, solarcell dinyatakan baik karena tegangan keluarannya berubah - ubah sesuai dengan intensitas cahaya matahari yang diterimanya.

Untuk mendapatkan daya listrik yang dihasilkan oleh solarcell pada satu jam sekali merupakan hasil perkalian dari tegangan keluaran dengan besarnya arus yang dihasilkan.

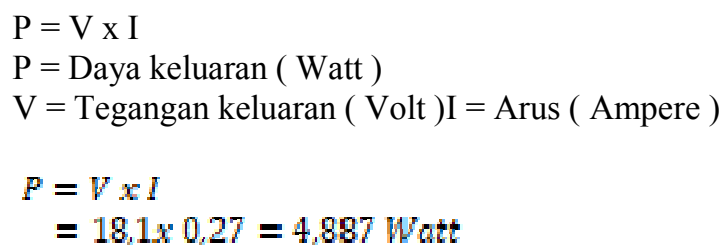

Untuk mendapatkan daya pada pengukuran ditiap jamnya dapat dihitung dengan metode yang sama. Maka dari hasil perhitungan dapat dilihat pada tabel berikut ini :

TABle V. Hasil Perhitungan Daya Tiap Jam

\begin{tabular}{ll}
\hline Waktu & Daya (Watt) \\
\hline 8.00 & 4,887 \\
9.00 & 5,930 \\
10.00 & 7,696 \\
11.00 & 7,696 \\
12.00 & 11,511 \\
13.00 & 12,753 \\
14.00 & 10,367 \\
15.00 & 8,658 \\
16.00 & 4,820 \\
\hline
\end{tabular}


Maka daya rata - rata yang diperoleh dari hasil pengukuran dari jam 8.00 - jam 16.00 sebesar 8,257 Watt Untuk mendapatkan energi listrik yang dihasilkan oleh solarcell dapat diperoleh melalui

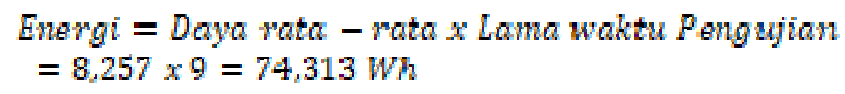

\section{Hasil Perancangan Alat}

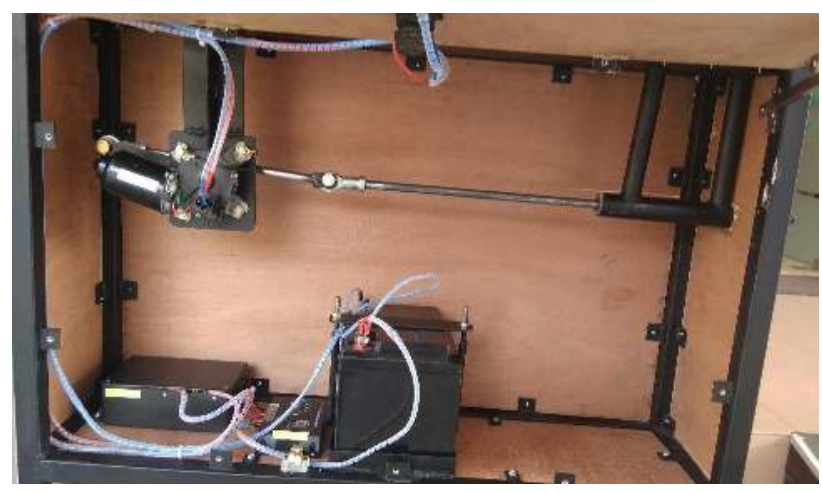

TABLE VI. BAGIAN DALAM ALAT MEKANIK DAN ELEKTRIK

\section{Uji Coba Alat Pada Sawah}

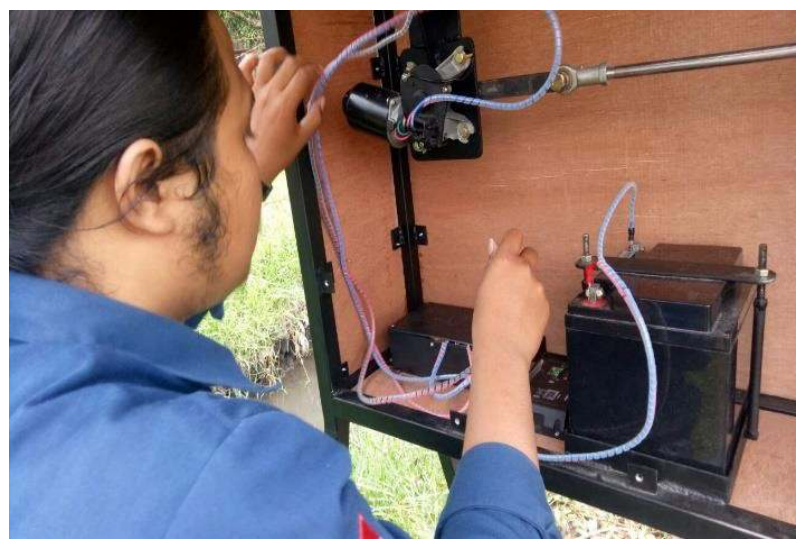

table VII. PengeceKan Alat Sebelum Uji Coba Di Sawah

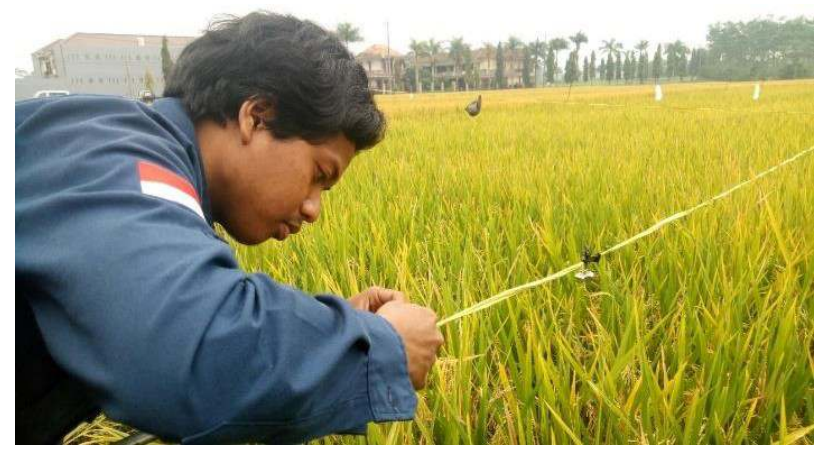

TABLE VIII. TALI DISETIAP BAGIAN SUDUT PETAK SAWAH UNTUK ALAT 


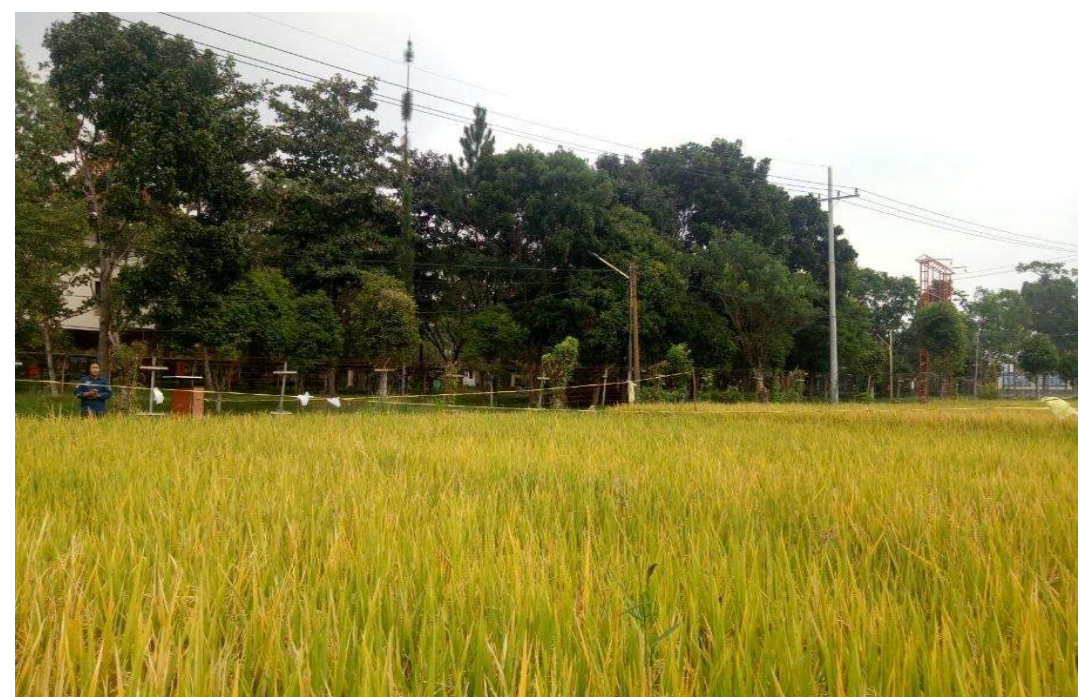

TABLE IX. UJI COBA ALAT PADA SAWAH

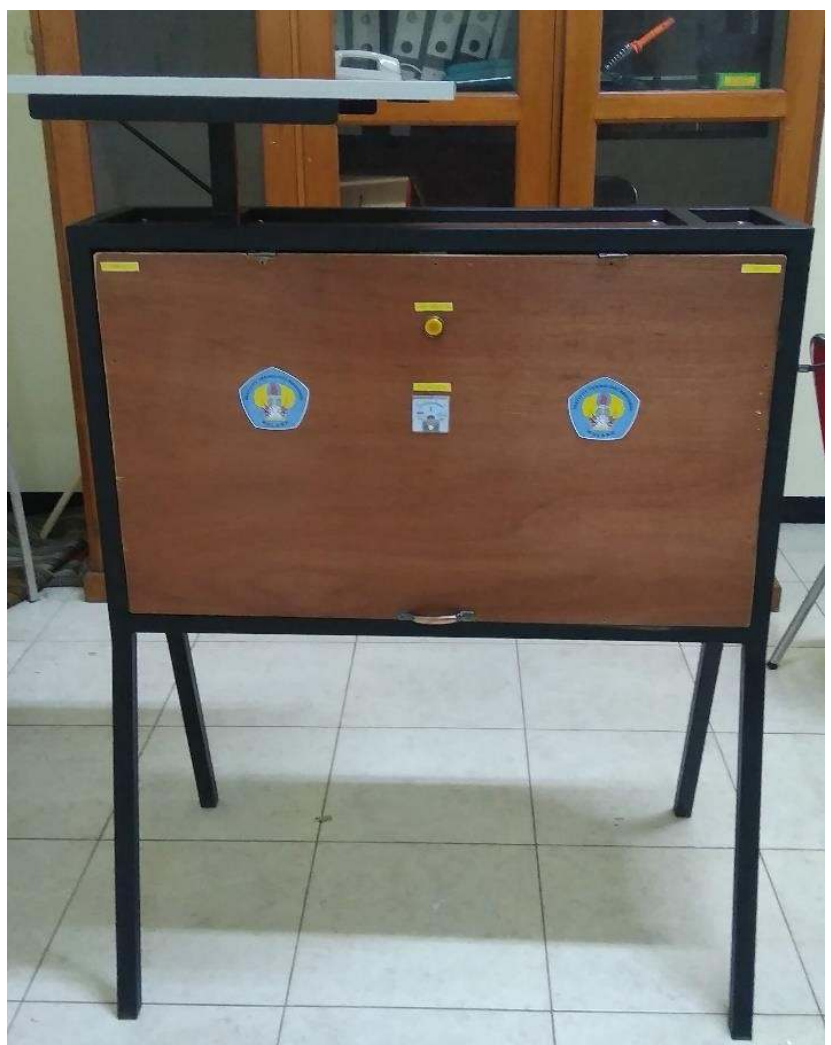

TABLE X. GAmbar Keseluruhan Alat

\section{SPESIFIKASI ALAT}

Spesifikasi pada alat Pengusir Burung sebagai berikut :

a) Ukuran Alat perajang rebung $\mathrm{P}=95, \mathrm{~T}=60, \mathrm{~L}=26$

b) Tegangan Akumulator 12 Volt

c) Tegangan Arduino Uno 5 Volt

d) Kecepatan Motor maks $=3421 \mathrm{rpm}$

e) Energi Solar cell rata-rata $=74,313 \mathrm{Wh}$

f) Daya rata-rata solar cell $=8,257$ Watt

g) Daya rata-rata motor $=2,3349 \mathrm{Watt}$ 


\section{KESIMPULAN}

Dari hasil pengabdian kepada masyarakat yang dilaksanakan dapat disimpulkan sebagai berikut :

a) Jarak jangkau bluetooth mencapai 45 meter dari peralatan

b) Daya yang dibutuhkan agar motor bekerja rata-rata $=2,3349$ Watt

c) Daya rata-rata yang dihasilkan Solar Cell 8,257 Watt

d) Daya minimal yang dihasilkan solar cell $=4,887$ Watt, maksimal $=4,820$ Watt

e) Dari data yang dihasilkan accumulator dapat digunakan satu hari penuh dimulai pukul 08.00-16.00 WIB.

\section{REFERENCES}

[1] https://id.wikipedia.org/wiki/Akumulator

[2] https://id.wikipedia.org/wiki/Motor listrik

[3] Zuhal, Dasar Teknik Tenaga Listrik dan Elektronika Daya, Edisi

[4] Kelima,Penerbit Gramedia, Jakarta, 1995.

[5] Mehta, V.K. \& Rohit Mehta, Principal of Electrical Machines, S. Chand \& Company Ltd, NewDelhi, 2002.

[6] Arduino. 2014. Arduino Uno R3. http://arduino.cc/en/Main/ArduinoBoardUno. Diakses 31November 2015.

[7] Pccomtrol, Pengetahuan Dasar mengirim-menerima SMS melalui Mikrokontroler (dengan ATCommandmodem GSM), 2012

[8] David Setiawan, Sistem Kontrol Motor Dc Menggunakan Pwm Arduino Berbasis Android System, Jurnal Sains, Teknologi dan Industri, Vol 15 No.1, Desember 2017, ISSN-1693-2390.

[9] Wijaya Widjanarka Natasaputra ${ }^{1 *}$,Sukris Sutiyatno ${ }^{2}$, Sepeda Motor Listrik Tenaga Matahari dengan Metode Wireless Energy Transfer, Teknik Informatika, STMIK Bina Patria Magelang

[10] https://teknologisurya.wordpress.com/dasar-teknologi-sel-surya/prinsip-kerja-sel-surya

[11] https://in.pinterest.com/pin/378935756127903973/

[12] https://docs.google.com/document/d/1kRvg54r4_M3NKa4S2f1jvwd0TaolXW_RoG-DdAWQ7w4/edit 